\title{
PELATIHAN PENELITIAN TINDAKAN KELAS (PTK) BAGI GURU-GURU SMKN I BENAKAT, MUARA ENIM
}

\author{
Yessi Fitriani ${ }^{1 *}$, Ratu Wardarita ${ }^{2}$, Missriani ${ }^{3}$, Dessy Wardiah ${ }^{4}$, Muhammad \\ Ali $^{5}$, Siti Rukiyah ${ }^{6}$, Puspa Indah Utami ${ }^{7}$, \\ Universitas PGRI Palembang ${ }^{1,2,3,4,6,7}$ \\ yessifitriani931@gmail.com
}

\begin{abstract}
Abstrak
Pengabdian kepada Masyarakat merupakan bentuk pelaksanaan pengamalan ilmu pengetahuan, teknologi dan seni budaya (IPTEKS) langsung pada masyarakat secara formal dalam usaha mengembangkan kemampuan masyarakat. Oleh karena itu, fokus dari kegiatan ini adalah peningkatan kemampuan atau profesionalitas guru/pendidik dalam bidang penelitian, yakni melalui penelitian tindakan kelas (PTK). Kegiatan pengabdian ini berbentuk workshop, berupa pelatihan guru dalam melakukan Penelitian Tindakan Kelas. Metode pelatihan ini dilakukan dengan metode: ceramah dan tanya jawab, demonstrasi, latihan dan praktik. Materi pelatihan disajikan dengan lebih banyak praktik daripada teori, dengan rasio perbandingan 25\% teori dan 75\% praktik. Tempat pelatihan dilakukan di ruang pertemuan di SMKN 1 Benakat, Muara Enim. Sasaran pada kegiatan pengabdian kepada masyarakat ini yaitu guru-guru SMKN 1 di Benakat, Muara Enim.
\end{abstract}

Keywords: Pelatihan, Penelitian Tindakan kelas, Pengabdian Kepada Masyarakat

\begin{abstract}
Community service is a form of implementing the practice of science, technology and cultural arts (IPTEKS) directly to the community formally in an effort to develop community capabilities. Therefore, the focus of this activity is to increase the ability or professionalism of teachers/educators in the field of research, namely through classroom action research. This service activity is in the form of a workshop, in the form of teacher training in Classroom Action Research. The training method is carried out using the following methods: lectures and questions and answers, demonstrations, exercises and practices. The training material is presented with more practice than theory, with a ratio of $25 \%$ theory and $75 \%$ practice. The training venue was held in the meeting room at SMKN 1 Benakat, Muara Enim. The target audience for this community service activity are vocational school teachers in SMKN 1 Benakat, Muara Enim.
\end{abstract}

Keywords: Training, Classroom Action Research, Community Service

Artikel disetujui tanggal:21-11-2021

Corresponden Author: Yessi Fitriani e-mail: yessifitriani931@gmail.com

DOI: http://dx.doi.org/10.31851/dedikasi.v4i2.6702 do

\section{PENDAHULUAN}

Pengabdian

kepada

Masyarakat (PkM) merupakan salah

satu pilar Tri Darma Perguruan

Tinggi, di samping darma pendidikan dan darma penelitian. Pengabdian kepada Masyarakat merupakan bentuk pelaksanaan pengamalan ilmu pengetahuan, teknologi dan seni budaya (IPTEKS) langsung pada 
Yessi Fitriani, Ratu Wardarita, Missriani, Dessy Wardiah, Muhammad Ali, Siti Rukiyah, Puspa Indah Utami (2021)

Pelatihan Penelitian Tindakan Kelas (PTK) Bagi Guru-Guru SMKN 1 Benakat Muara Enim WAHANA DEDIKASI

masyarakat secara formal dalam usaha mengembangkan kemampuan masyarakat, sehingga pada akhirnya diharapkan dapat mempercepat tercapainya tujuan pendidikan.Maka dari itu, fokus dari kegiatan PPM ini adalah peningkatan kemampuan atau profesionalitas guru/pendidik dalam bidang penelitian, yakni melalui penelitian tindakan kelas (selanjutnya disingkat PTK).

Setiap guru profesional wajib melakukan pengembangan profesi. Salah satu bentuk kegiatan ini adalah menulis karya tulis ilmiah berupa hasil penelitian tindakan kelas. PTK sesungguhnya merupakan implementasi dari kreativitas dan kekritisan seorang guru terhadap apa yang sehari-hari diamati dan dialaminya sehubungan dengan profesinya untuk menghasilkan kualitas pembelajaran yang lebih baik sehingga mencapai hasil belajar yang optimal.

Salah satu kegiatan yang sangat urgen dan perlu berkelanjutan dilakukan adalah memberikan pendampingan kepada para guru dalam meningkatkan kompetensi pedagogi di kelas. Depdiknas (2004) menyebut kompetensi ini dengan "kompetensi pengelolaan pembelajaran". Undang-Undang No. 14 Tahun 2005 tentang Guru dan Dosen menjelaskan kompetensi pedagogik adalah "kemampuan mengelola pembelajaran peserta didik".

Guru mempunyai hak dan kewenangan untuk membimbing dan mengarahkan anak didik agar mereka bisa menjadi manusia yang berilmu pengetahuan di masa depan (Djamarah, 2008). Bilamana guru pasif, stagnan, dan malas dalam melakukan kajian, analisis, dan melakukan penelitian yang serius, maka pendidikan di negeri kita ini akan terus ketinggalan dengan negara-negara lain. Bangsa lain begitu aktif dan konsisten dalam mendorong aspek penelitian di dunia pendidikan.

Banyak persoalan yang dihadapi guru pada waktu berdiri di depan kelas. Berbagai solusi atau cara penyelesaian masalah juga sudah banyak dibahas dalam berbagai telaah penelitian akademik, baik dalam laporan penelitian berbentuk artikel atau pada jenjang skripsi, tesis, 
Yessi Fitriani, Ratu Wardarita, Missriani, Dessy Wardiah, Muhammad Ali, Siti Rukiyah, Puspa Indah Utami (2021)

Pelatihan Penelitian Tindakan Kelas (PTK) Bagi Guru-Guru SMKN 1 Benakat Muara Enim VAHANA DEDIKASI

bahkan disertasi. Akan tetapi, guru tidak dapat memahaminya, apalagi mengaplikasikannya dalam pembelajaran sehari-hari, terutama karena berbagai kendala. Misalnya, guru tidak terlalu memahami teoriteori yang dijadikan landasan atau alat analisis penelitian tersebut. Apa yang mereka butuhkan adalah penelitian pendidikan yang membatasi kegunaannya kepada kebutuhan sehari-hari, agar dapat dimanfaatkan guru yang ingin memperbaiki kinerjanya, sehingga untuk memenuhi tuntutan tersebut, guru dapat menggunakan penelitian tindakan kelas (Wiriaatmadja, 2007).

Pelatihan penelitian tindakan kelas ini bertujuan untuk memperbaiki/meningkatkan kualitas pembelajaran secara berkesinambungan, kualitas hasil belajar agar menjadi lebih baik, kualitas inovasi dan kreatif kurikulum yang bisa dikembangkan oleh guru, strategi pembelajaran dan penilaian berbasis kompetensi yang juga bisa dikembangkan oleh guru, dan pada akhirnya kualitas pendidikan di sekolah tempat guru tersebut mengajar akan meningkat (Tampubolon, 2014).

Manfaat penelitian tindakan kelas bagi guru adalah agar guru menjadi lebih professional dengan meningkatnya: (1) kompetensi guru dalam mengatasi masalah pembelajaran yang menjadi tugas utamanya, (2) sikap profesional guru, (3) kualitas belajar atau kompetensi siswa, (4) kualitas proses pembelajaran di kelas, (5) kualitas penggunaan media, (6) alat bantu belajar dan sumber belajar lainnya, (7) kualitas prosedur dan alat evaluasi yang digunakan untuk mengukur proses dan hasil belajar siswa, (8) kulaitas pengembangan pribadi siswa di sekolah, dan (9) peningkatan kualitas kurikulum (Muslich, 2014).

Langkah-langkah membuat penelitian tindakan kelas adalah: (1) melakukan identifikasi masalah, (2) memfokuskan masalah yang telah teridentifikasi, (3) mendiagnosis kemungkinan penyebab masalah dan alternatif tindakan perbaikannya, (4) merumuskan pemecahan masalah dalam bentuk hipotesis tindakan, (5) menganalisis kelaikan hipotesis tindakan, 6) menyusun serangkaian 
Yessi Fitriani, Ratu Wardarita, Missriani, Dessy Wardiah, Muhammad Ali, Siti Rukiyah, Puspa Indah Utami (2021)

Pelatihan Penelitian Tindakan Kelas (PTK) Bagi Guru-Guru SMKN 1 Benakat Muara Enim W/AHANA DEDIKASI

tindakan yang dapat memecahkan masalah yang ada, (7) menyusun cara untuk mengumpulkan data dan instrumen penelitian untuk mendapatkan data yang valid, dan (8) melakukan analisis data yang dikumpulkan (Muslich, 2014).

Secara umum, penelitian tindakan kelas terdiri atas beberapa siklus atau pengulangan dari siklus. Setiap siklus terdiri atas empat langkah, yaitu: (1) perencanaan, (2) pelaksanaan,

pengamatan/observasi, dan

refleksi. Keempat tahapan tersebut merupakan unsur yang membentuk sebuah siklus, yaitu satu putaran kegiatan beruntun. Dengan demikian, bentuk penelitian tindakan kelas tidak pernah merupakan kegiatan tunggal, tetapi berupa rangkaian kegiatan yang akan kembali ke bentuk asal, yaitu siklus. Setiap satu siklus terdiri dari empat tahap sebagai berikut. (1) Tahap perencanaan. Pada tahap ini, peneliti harus mempersiapkan secara matang bentuk penelitian yang dirancang dalam rangka perbaikan pembelajaran yang dilakukan. (2) Tahap pelaksanaan. Tahap pelaksanaan merupakan tahap mengeksekusi rencana pembelajaran yang telah dibuat sebelumnya. (3) Tahap pengamatan: Pada tahap ini hal yang harus diperhatikan adalah kegiatan belajar siswa dan kegiatan mengajar. Selama kegiatan dilakukan observasi baik terhadap guru maupun terhadap siswa. Hasil observasi dalam proses pembelajaran dan hasil belajar setelah pembelajaran berlangsung menjadi acuan untuk tahap selanjutnya. (4) Tahap refleksi. Pada tahap ini dilakukan refleksi atas semua data observasi dan hasil belajar yang diperoleh selama pembelajaran yang dilakukan di kelas, apakah perlu dilakukan siklus kedua atau tidak. Jika diputuskan akan melakukan siklus kedua, maka dilakukan perencanaan ulang sebagai hasil refleksi dari siklus pertama. Sebaiknya, pada tahapan refleksi ini ada diskusi antara guru (peneliti) dan kolaborator yang mengamati kegiatan belajar selama penelitian berlangsung. Tujuannya agar mendapat masukan dari kolaborator terhadap kinerja guru sebagai peneliti selama pembelajaran di kelas (Arikunto, 2012). 
Yessi Fitriani, Ratu Wardarita, Missriani, Dessy Wardiah, Muhammad Ali, Siti Rukiyah, Puspa Indah Utami (2021)

Pelatihan Penelitian Tindakan Kelas (PTK) Bagi Guru-Guru SMKN 1 Benakat Muara Enim W/AHANA DEDIKASI

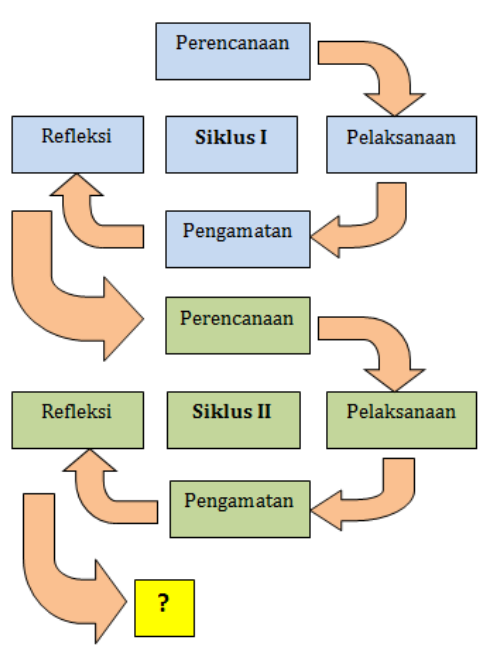

Gambar 1. Skema siklus dalam Peneltian Tindakan Kelas (Arikunto, 2012)

Penulisan karya ilmiah bagi guru harus dipandang sebagai suatu kelaziman dalam melaksanakan tugasnya, sehingga tidak dipandang sebagai hal yang sangat menakutkan dan memberatkan bagi guru tetapi sebaliknya sebagai hal yang sangat menggairahkan. Hal ini menjadi persoalan serius, yaitu guru tidak dapat naik pangkat karena tidak mampu menghasilkan karya tulis ilmiah, jika para guru tidak mempersiapkan diri untuk menulis karya tulis ilmiah berupa PTK. Persoalan tersebut akan benar terjadi, jika tanpa adanya pelatihan, pembimbingan, dan pendampingan bagi para guru di sekolah dalam melaksanakan PTK. Oleh karena itu, melalui kegiatan PkM ini akan memberikan pelatihan, pembimbingan dan pendampingan kepada guru di SMAN 1 Benakat, Muara Enim untuk melaksanakan PTK. Target kegiatan PkM ini, memberikan pelatihan dan pembimbingan PTK kepada para guru di SMAN 1 Benakat, Muara Enim. Setelah diberikan pelatihan selanjutnya guru akan melakukan praktik membuat proposal PTK, melakukan PTK dan akhirnya mampu membuat laporan PTK.

Dengan melaksanakan PTK, diharapkan guru memiliki peran ganda yaitu sebagai praktisi dan sekaligus peneliti. Dengan demikian, dapat disimpulkan bahwa PTK adalah suatu kegiatan penelitian yang dilakukan guru di dalam kelasnya dengan permasalahan diperoleh dari kegiatan refleksi diri dan disertai suatu tindakan dengan tujuan untuk menyelesaikan masalah tersebut atau meningkatkan mutu pembelajaran yang dilakukan.

\section{BAHAN DAN METODE}

Kegiatan ini dilaksanakan pada 21 Juni 2021 bertempat di SMK 
Yessi Fitriani, Ratu Wardarita, Missriani, Dessy Wardiah, Muhammad Ali, Siti Rukiyah, Puspa Indah Utami (2021)

Pelatihan Penelitian Tindakan Kelas (PTK) Bagi Guru-Guru SMKN 1 Benakat Muara Enim

\section{WAHANA DEDIKASI}

Negeri 1 Benakat, Muara Enim.

Peserta pelatihan adalah guru-guru di sekolah tersebut berjumlah 28 orang. Narasumber dalam kegiatan ini adalah dosen-dosen Program Studi Magister Pendidikan Bahasa Indonesia Universitas PGRI Palembang. Sebelum pelaksanaan dilakukan terlebih dahulu mempersiapkan materi yang akan disampaikan melalui power point.

Metode pelatihan dilakukan dengan metode: ceramah dan tanya jawab, demonstrasi, latihan dan praktik. Materi pelatihan disajikan dengan lebih banyak praktik dari teori, dengan rasio perbandingan $25 \%$ teori dan $75 \%$ praktik. Tempat pelatihan dilakukan di ruang pertemuan di SMKN 1 Benakat Muara Enim. Setelah dilakukan pelatihan, guru diberikan penugasan untuk membuat draft proposal PTK, untuk selanjutnya diberikan pelatihan dan pendampingan terhadap draft proposal yang telah dibuat oleh guru.

\section{HASIL DAN PEMBAHASAN}

Pelaksanaan Pengabdian kepada Masyarakat ini dilaksanakan 21 Juni 2021 di SMK Negeri 1 Benakat, Muara Enim berjalan dengan baik dan lancar. Guru-guru yang mengikuti kegiatan pelatihan PTK ini diharapkan dapat merumuskan judul penelitian PTK, merancang proposal PTK, melaksakan PTK dan membuat laporan PTK. Untuk mencapai tujuan tersebut guru -guru diberikan materi: (1) Kebijakan Profesionalisme guru di Indonesia, (2) Wawasan Praktis tentang PTK, (3) Identifikasi dan Analisis Masalah dalam PTK, (4) Menentukan Tindakan dan Merumuskan Judul PTK, (5) Merancang Proposal PTK dan RPP PTK, (6) Membuat Laporan PTK. Langkah pertama berupa latihan mengangkat masalah di dalam kelas yang kemudian menjadi permasalahan untuk penelitian tindakan kelas. Pada materi pertama berupa "Pendahuluan dalam Penelitian Tindakan Kelas", guru diberikan materi Pendahuluan yang merupakan bab awal yang harus dibuat dalam penyusunan sebuah laporan penelitian, termasuk penelitian tindakan kelas. Pendahuluan yang terdiri dari komponen berikut: (1) Latar Belakang Masalah, (2) Perumusan 
Yessi Fitriani, Ratu Wardarita, Missriani, Dessy Wardiah, Muhammad Ali, Siti Rukiyah, Puspa Indah Utami (2021)

Pelatihan Penelitian Tindakan Kelas (PTK) Bagi Guru-Guru SMKN 1 Benakat Muara Enim WAHANA DEDIKASI

Masalah, (3) Tujuan Penelitian, dan

(4) Manfaat Penelitian.

Pada materi kedua yakni "Landasan Teori (PTK suatu Tinjauan Teoretis)", guru diberikan penjelasan dengan menciptakan landasan teori yang baik dalam penelitian akan menjadi salah satu hal terpenting, karena landasan teori menjadi sebuah landasan dalam penelitian itu sendiri. Dalam menyusun sebuah landasan teori terdapat beberapa hal yang perlu diperhatikan oleh seorang peneliti, yaitu: (1) sebaiknya seorang peneliti memakai panduan yang berhubungan dengan berbagai permasalahan yang sedang ditelitinya dan panduan yang berisikan hasil penelitian sebelumnya. (2) Penulisan antarsubab yang lainnya harus tetap saling terhubung dengan jelas serta harus memperhatikan aturan-aturan dari penulisan pustaka. (3) Agar mendapatkan hasil penelitian yang baik dan benar, studi pustaka harus memenuhi prinsip kemutakhiran dan juga harus berhubungan dengan masalah penelitian.

Pada materi ketiga yakni "Metodologi Penelitian Tindakan
Kelas", guru diberikan penjelasan tentang metode yang digunakan dalam proses penelitian tindakan kelas. Metode PTK dijalankan berdasarkan model PTK yang telah ada. Model PTK yang bisa dijadikan pilihan adalah Model Kurt Lewin, Model Kemmis \& McTaggart, Model John Elliot, dan Model Hopkins.

Pada materi keempat yakni "Hasil dan Pembahasan". Materi kelima yakni "Kesimpulan dan Saran". Para guru diberikan penjelasan bahwa simpulan yaitu menjelaskan jawaban singkat atas pertanyaan penelitian yang diajukan secara sistematis sedangkan saran memberikan rekomendasi dari hasil penelitian.

Kegiatan untuk membangun pemahaman terhadap konsep penelitian tindakan kelas serta desain dan prosedurnya dilakukan ceramah dan diskusi yang diikuti dengan kegiatan umpan-balik antara penyaji dengan guru-guru. Berdasarkan hasil jawaban umpan balik yang disampaikan oleh guru, menunjukkan bahwa guru SMKN 1 Benakat Muara Enim memahami konsep subtansial dari PTK dan prosedur yang harus 
Yessi Fitriani, Ratu Wardarita, Missriani, Dessy Wardiah, Muhammad Ali, Siti Rukiyah, Puspa Indah Utami (2021)

Pelatihan Penelitian Tindakan Kelas (PTK) Bagi Guru-Guru SMKN 1 Benakat Muara Enim

\section{WAHANA DEDIKASI}

dilakukan untuk melaksanakan PTK.

Pesan dan kesan yang disampaikan peserta cukup antusias. Mereka mendapatkan informasi baru yang bermanfaat untuk menambah wawasan peserta pelatihan. Mereka juga menjadi termotivasi untuk membuat PTK yang nantinya tentu saja dapat menunjang karir mereka sebagai guru. Harapan mereka pelatihan ini dapat berkelanjutan hingga penelitian ini menjadi artikel yang dapat dipublikan ke jurnal.

\section{KESIMPULAN}

Berdasarkan hasil yang diperoleh dalam pelaksanaan kegiatan Pengabdian kepada Masyarakat ini dapat disimpulkan bahwa kegiatan ini telah memberikan kontribusi kepada guru-guru SMKN I Benakat, Muara Enim, yakni membuat Penelitian Tindakan Kelas (PTK). Kesimpulan dari pelatihan penyusunan proposal PTK ini sebagian besar peserta pelatihan memberikan respon yang baik terhadap pelatihan ini dengan memberikan tanggapan positif. Pesan dan kesan yang diberikan sangat baik. Kekurangan dari pelatihan ini adalah belum dilakukan evaluasi secara sistematis terhadap laporan hasil PTK para guru tersebut. Hal ini akan ditindaklanjuti pada pelatihan selanjutnya.

\section{DAFTAR PUSTAKA}

Arikunto, Suharsimi. (2012). Penelitian Tindakan Kelas, Jakarta: PT Bumi Aksara.

Djamarah, Syaiful Bahri. (2008). Psikologi Belajar. Jakarta: PT Rineka Cipta.

Muslich, Masnur. (2014). Melaksanakan PTK (Penelitian Tindakan Kelas) Itu Mudah. Jakarta: PT Bumi Aksara. Tampubolon, Saur. (2014). Penelitian Tindakan Kelas sebagai Pengembangan Profesi Pendidik dan Keilmuan. Jakarta: Erlangga.

Undang-undang No. 14 Tahun 2005 tentang Guru dan Dosen.

Wiriaatmadja, Rochiati. (2007). Metode Penelitian Tindakan Kelas. Bandung: PT Remaja Rosdakarya. 
Yessi Fitriani, Ratu Wardarita, Missriani, Dessy Wardiah, Muhammad Ali, Siti Rukiyah, Puspa Indah Utami (2021)

Pelatihan Penelitian Tindakan Kelas (PTK) Bagi Guru-Guru SMKN 1 Benakat Muara Enim W/AHANA DEDIKASI

82 | Wahana Dedikasi Copyright@Yessi Fitriani 